\title{
The Effect of 2-Methoxyethanol and Methoxyacetic Acid on Sertoli Cell Lactate Production and Protein Synthesis in Vitro
}

\author{
P. J. BeATtie, ${ }^{1}$ M. J. Welsh, ${ }^{*}$ AND M. J. BRABEC \\ Toxicology Program, Department of Environmental and Industrial Health, and ${ }^{*}$ Department of Anatomy \\ and Cell Biology. The University of Michigan, Ann Arbor, Michigan 48109
}

Received February 18, 1984; accepted May 23, 1984

\begin{abstract}
The Effect of 2-Methoxyethanol and Methoxyacetic Acid on Sertoli Cell Lactate Production and Protein Synthesis in Vitro. Beattie, P. J., Welsh, M. J., AND BRaBeC, M. J. (1984). Toxicol. Appl. Pharmacol. 76, 56-61. Exposure to 2-methoxyethanol (ME) or its major metabolite, methoxyacetic acid (MA), results in spermatocyte depletion and testicular atrophy in experimental animals. The site of spermatogenesis is within the seminiferous tubule. Sertoli cells support spermatogenesis, synthesizing and secreting proteins, and metabolic substrates for utilization by differentiating germ cells in the seminiferous tubule lumen. One of these substrates, lactate, is preferentially metabolized by spermatocytes. Therefore, because germ cells are dependent upon the metabolic products of Sertoli cells, the effect of ME and MA on production of lactate and protein synthesis was measured in cultured rat Sertoli cells. Cell cultures were incubated with ME or MA at 0,3 , or $10 \mathrm{mM}$ for up to $12 \mathrm{hr}$. No significant difference was seen in total protein synthesis as measured by $\left[{ }^{3} \mathrm{H}\right]$ leucine incorporation. ME and MA had no apparent effect on cell viability. However, lactate concentrations and rates of lactate accumulation were significantly decreased by MA, but not ME, at both 3 and $10 \mathrm{mM}$ following incubation for 6,9 , and $12 \mathrm{hr}$. The results suggest that inhibition of Sertoli cell lactate production resulting from ME or MA exposure could account for the inhibitory action of these compounds on spermatogenesis. (c) 1984 Academic Press, Inc.
\end{abstract}

2-Methoxyethanol (ME; ethylene glycol monomethyl ether; CAS No. 109-86-4) is a glycol ether, which, because of its unique solvent characteristics, has found numerous applications as a component in surface coatings, inks, dyes, hydraulic brake fluids, and water-based cleaners.

Exposure to ME causes testicular damage in experimental animals. Inhalation studies by Miller $e$ al. (1981, 1983a) with ME at concentrations up to $1000 \mathrm{ppm}$ for periods from 9 days to 13 weeks revealed testicular changes as well as adverse effects on bone marrow and lymphoid tissues in rats, mice, and rabbits. The changes in the testicular

\footnotetext{
' To whom correspondence should be sent: General Motors Corp., 3044 W. Grand Blvd., Detroit, Mich. 48202.
}

germinal epithelium of rats after 9 days of inhalation exposure to $1000 \mathrm{ppm}$ ME were diffuse and severe, with degeneration and necrosis of all spermatogenic elements and formation of spermatidic giant cells. Doe et al. (1983) observed degeneration of primary spermatocytes and spermatids, with spermatogonia, and Sertoli and Leydig cells apparently unaffected in rats exposed to 300 ppm ME for 10 days. In rats exposed for 4 days to $150 \mathrm{mg} / \mathrm{kg} \mathrm{ME}$, spermatocytes and round spermatids were necrotic and often missing (Chapin, 1983). Foster et al. (1983) reported that, $24 \mathrm{hr}$ after a single dose in rats of $100 \mathrm{mg} / \mathrm{kg}$ ME, the initial testicular lesion appeared to be a depletion of primary spermatocytes. In addition, $16 \mathrm{hr}$ after a single dose of $500 \mathrm{mg} / \mathrm{kg}$, spermatocyte mitochondrial swelling and disruption, cytoplasmic 
vacuolization, and early condensation of nuclear chromatin were observed (Foster et al., 1983). Samuels et al. (1983) found ME to affect primary and secondary spermatocytes within $24 \mathrm{hr}$ after exposure to $1000 \mathrm{ppm}$. Some fragmentation of Sertoli cells was also found.

Methoxyacetic acid (MA; CAS No. 62545-6) has been identified as the primary metabolite of ME in rats (Miller et al., 1983b). Miller et al. (1982) demonstrated that the toxicological properties of MA are remarkably similar to ME, and concluded that the toxicity of ME is probably due to its metabolite, MA. Thus, spermatogenesis also appears to be a very sensitive target following MA exposure.

Spermatogenesis occurs in the seminiferous tubules of the testes. Within the seminiferous tubule, the Sertoli cells function, in part, as nurse cells, synthesizing and secreting proteins and metabolic substrates into the lumen of the tubule for the differentiating germ cells (Skinner and Griswold, 1983; Kissinger et al., 1982; Waites and Gladwell, 1982). Sertoli cells metabolize glucose primarily to lactate (Robinson and Fritz, 1981), which may be the prime metabolic substrate of cells early in the spermatogenic cycle (Jutte et al., 1981; 1982). Thus, alterations in Sertoli cell function induced by ME or MA could be critical for spermatocyte viability and maintenance of spermatogenesis. For these reasons, the effects of ME and MA on lactate production and protein synthesis by cultured Sertoli cells were investigated.

\section{METHODS}

Test materials. MF and MA, approximately $99 \%$ pure, were purchased from Aldrich Chemical Company, Milwaukee, Wisconsin. $\left[{ }^{3} \mathrm{H}\right]$ Leucine, $1 \mathrm{Ci} / \mathrm{mmol}$, was purchased from Amersham Corporation, Arlington Heights, Illinois. All other chemicals were purchased from Sigma Chemical Company, St. Louis, Missouri.

Animals. Male Sprague-Dawley CD rats, 21 days old, were purchased from Charles River Breeding Laboratories, Inc., Wilmington, Massachusetts. The animals were killed upon arrival.

Sertoli cell preparation. Sertoli cells were isolated essentially by the method of Welsh and Wiebe (1975).
All glassware and surgical equipment were sterilized prior to use. Testes from 10 to 12 rats were removed and placed in ice-cold, magnesium-free, phosphate-buffered saline consisting of $97.6 \mathrm{mM} \mathrm{NaCl}, 25 \mathrm{mM} \mathrm{KCl}, 3.7 \mathrm{mM}$ $\mathrm{Na}_{2} \mathrm{HPO}_{4}, 8.3 \mathrm{~mm}$ glucose, $50 \mathrm{U} / \mathrm{ml}$ penicillin, $50 \mu \mathrm{g} /$ $\mathrm{ml}$ streptomycin sulfate, and $0.008 \mathrm{mM}$ phenol red in deionized, distilled water, $\mathrm{pH} 7.4$ (adjusted with $\mathrm{KH}_{2} \mathrm{PO}_{4}$ ). The tissues were rinsed in saline solution, detunicated, placed in a 50-ml stoppered flask, and rinsed twice with buffered saline. The testes were placed in a sterile 100 mm-diameter plastic Petri dish and minced into pieces about $2 \mathrm{~mm}$ square with a stainless-steel razor blade. The minced tissue was placed in a stoppered flask and washed twice by adding $30 \mathrm{ml}$ of saline solution. The flask was placed on ice, and the tissue mince was allowed to sediment. The supernatant fraction was discarded, and the tissue mince was divided into two $50-\mathrm{ml}$ stoppered flasks with approximately $1 \mathrm{~g}$ tissue, $20 \mathrm{ml}$ saline solution, and $2 \mathrm{mg}$ collagenase (Sigma, type IV, $160 \mathrm{U} / \mathrm{mg}$ ) per flask. These were incubated at $32^{\circ} \mathrm{C}$ in a shaker bath at 135 oscillations/min for approximately $55 \mathrm{~min}$. At the end of this time, a reaggregated mass of tissue, composed primarily of interstitial cells, was removed, leaving tubule fragments in suspension. The tissue mass was washed twice in saline solution to harvest more tubule fragments, and was then discarded. The washed tubule fragments were combined, allowed to sediment, and were washed twice as described above. The tubule fragments were divided into two $50-\mathrm{ml}$ stoppered flasks with approximately $0.25 \mathrm{~g}$ tissue, $20 \mathrm{ml}$ saline solution, and $2 \mathrm{mg}$ pancreatin (Sigma, grade VI, porcine, activity: $4 \times \mathrm{NF}$ grade) per flask. After 15 to $20 \mathrm{~min}$. agitation as before, a mass of aggregated tissue, composed primarily of peritubular cells, was removed, washed twice to obtain more tubule fragments, and was discarded. The tubule fragments were combined into one flask and allowed to sediment. The supernatant fraction was then decanted, and an additional $30 \mathrm{ml}$ saline solution was added to the flask. This suspension of tubule fragments and clusters of cells was filtered through a sterile, fine-mesh, stainlesssteel screen into a $50-\mathrm{ml}$ sterile plastic centrifuge tube and placed on ice to settle. The supernatant fraction was discarded, and the cells were poured into a $15-\mathrm{ml}$ sterile plastic centrifuge tube. The cells were washed twice by centrifuging at about $100 \mathrm{~g}$ for $5 \mathrm{~min}$. The packed cell volume was estimated, and the cells were suspended in an appropriate volume of culture medium so that approximately $10^{6}$ cells were plated in each culture dish (60 mm diameter, Falcon). The Sertoli cells were cultured for 3 days in serum-free medium based on a 50:50 F12/ DMEM formula with added insulin, epidermal growth factor, and transferrin (Mather, 1980) as well as $1 \mu \mathrm{g} / \mathrm{ml}$ FSH [ovine, NIH-FSH-S12, National Pituitary Agency (NIAMDD)], and incubated at $32^{\circ} \mathrm{C}$ in $5 \% \mathrm{CO}_{2}-95 \%$ air atmosphere. Microscopic examination of the plates confirmed that the cultures consisted almost exclusively of Sertoli cells (Fig. 1). 


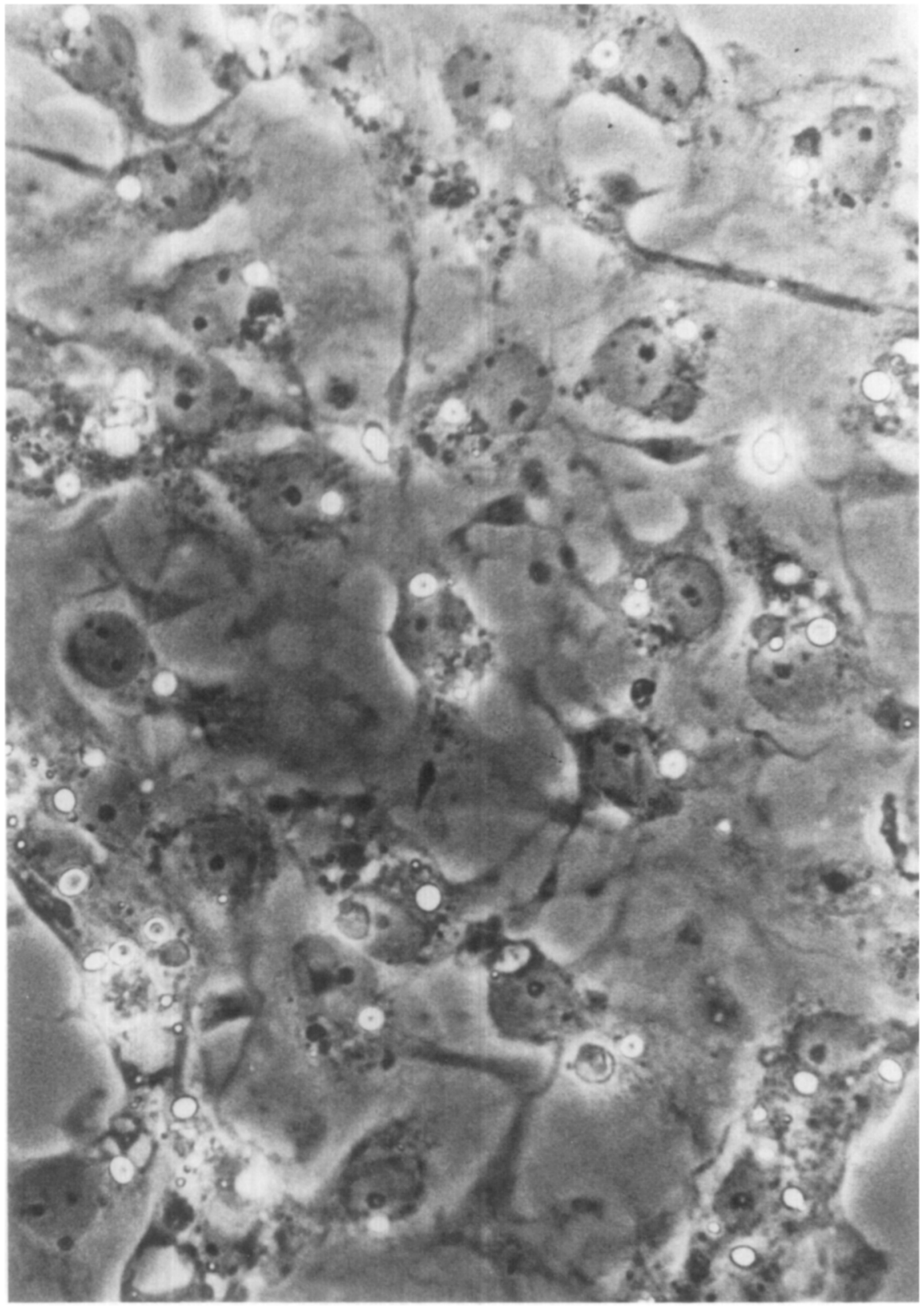

FIG. 1. Sertoli cells were cultured for 3 days $\left(32^{\circ} \mathrm{C}, 5 \% \mathrm{CO}_{2}-95 \%\right.$ air atmosphere) in serum-free medium based on a 50:50 F12/DMEM formula with added insulin, epidermal growth factor, and transferrin (Mather, 1980), as well as FSH $(1 \mu \mathrm{g} / \mathrm{ml})$ to maximally stimulate cellular lactate production and protein synthesis. $(\times 800)$.

Incubation of Sertoli cell cultures with $M E$ or $M A$. Prior to addition of ME or MA, Sertoli cells were incubated for $2 \mathrm{hr}$ in modified culture medium (medium without lactate, pyruvate, or leucine). The incubation was initiated by replacement with fresh modified medium containing $\left[{ }^{3} \mathrm{H}\right]$ leucine, $25 \mu \mathrm{Ci}$ /plate. ME or MA (pH 
adjusted to 7.4) was then added at 0,3 , or $10 \mathrm{~mm}$ (five plates per dose). Cycloheximide, $50 \mu \mathrm{g} / \mathrm{ml}$, was added to at least one plate per experiment as a positive control for protein synthesis. At $0,1,3,6,9$, and $12 \mathrm{hr}, 0.1-\mathrm{ml}$ aliquots of incubation medium were removed from each plate for lactate determinations.

Lactate determinations. Lactate concentrations in aliquots of culture medium were measured in duplicate by spectrophotometric measurement $(340 \mathrm{~nm})$ of the stochiometric conversion of lactate to pyruvate with concomitant reduction of NAD by lactate dehydrogenase (Hohorst, 1965, as modified by Brabec et al., 1984).

Protein synthesis determinations. Protein synthesis was measured as the incorporation of $\left[{ }^{3} \mathrm{H}\right]$ leucine into acid-insoluble material essentially as described (Tash $\boldsymbol{e t}$ al., 1981). At the end of the 12-hr incubation, the remaining radioactive medium was aspirated into vacutainer tubes. The plates were gently rinsed twice with the standard culture medium (containing leucine, lactate, and pyruvate). The cells were then removed from each plate with a rubber policeman and suspended in $2 \mathrm{ml}$ medium. A $0.5-\mathrm{ml}$ aliquot of this cell suspension was removed for protein determination. The remainder was acidified with $1.5 \mathrm{ml}$ ice-cold $10 \%$ trichloroacetic acid (TCA) solution. This material was then rinsed onto a Whatman filter ( $2.4 \mathrm{~cm}$ GF/A) in a BioRad vacuum manifold, and washed with ice-cold 5\% TCA solution. The filter paper was placed in a scintillation vial with 10 $\mathrm{ml}$ of OCS liquid scintillation mixture (Amersham), and radioactivity was determined in a Packard liquid scintillation spectrometer.

Protein determinations. Protein determinations were made by the method of Bradford (1976).

Analysis of data. One-way analysis of variance was

TABLE 1

Lactate Levels in Sertoli Cell Culture Medum FOLLOWING INCUBATION WITH 2-METHOXYETHANOL

\begin{tabular}{cccc}
\hline & \multicolumn{3}{c}{ Lactate levels $(\mu \mathrm{g} / \mathrm{ml})^{a}$} \\
\cline { 2 - 4 } $\begin{array}{c}\text { Incubation time } \\
(\mathrm{hr})\end{array}$ & $\begin{array}{c}\text { Controls } \\
(n=5)\end{array}$ & $\begin{array}{c}3 \mathrm{mM} \\
(n=5)\end{array}$ & $\begin{array}{c}10 \mathrm{mM} \\
(n=5)\end{array}$ \\
\hline 0 & $17.94 \pm 0.62$ & $18.63 \pm 0.72$ & $23.00 \pm 2.37$ \\
1 & $28.13 \pm 0.84$ & $29.67 \pm 2.61$ & $24.85 \pm 2.63$ \\
3 & $33.53 \pm 2.82$ & $33.72 \pm 2.28$ & $34.49 \pm 2.03$ \\
6 & $50.86 \pm 0.92$ & $49.90 \pm 1.00$ & $50.67 \pm 1.65$ \\
9 & $69.55 \pm 1.26$ & $65.12 \pm 3.14$ & $67.05 \pm 1.67$ \\
12 & $86.50 \pm 2.05$ & $76.79 \pm 3.47$ & $87.08 \pm 5.05$ \\
$\left.\begin{array}{c}\text { Accumulation } \\
\left(\mu \mathrm{g} \text { ml }{ }^{-1} \text { hr }\right.\end{array}{ }^{-1}\right)$ & $5.57 \pm 0.21$ & $4.72 \pm 0.27$ & $5.39 \pm 0.44$ \\
$\begin{array}{c}\text { Coefficient of } \\
\text { correlation }(r)\end{array}$ & 0.992 & 0.984 & 0.986 \\
\hline
\end{tabular}

${ }^{*}$ Mean \pm SE.
TABLE 2

lactate levels in Sertoli Cell. Culture Medium FOLLOWING INCUBATION WITH METHOXYACETIC ACID

\begin{tabular}{|c|c|c|c|}
\hline \multirow[b]{2}{*}{$\begin{array}{l}\text { Incubation time } \\
\text { (hr) }\end{array}$} & \multicolumn{3}{|c|}{ Lactate levels $(\mu \mathrm{g} / \mathrm{ml})^{2}$} \\
\hline & $\begin{array}{c}\text { Controls } \\
(n=5)\end{array}$ & $\begin{array}{c}3 \mathrm{mM} \\
(n=5)\end{array}$ & $\begin{array}{l}10 \mathrm{mM} \\
(n=5)\end{array}$ \\
\hline 0 & $13.79 \pm 1.16$ & $15.03 \pm 1.49$ & $16.75 \pm 1.88$ \\
\hline 1 & $21.96 \pm 1.75$ & $19.66 \pm 1.04$ & $21.77 \pm 1.27$ \\
\hline 3 & $33.91 \pm 1.91$ & $32.95 \pm 3.55$ & $25.82 \pm 4.28$ \\
\hline 6 & $45.08 \pm 1.35$ & $37.95 \pm 2.19^{*}$ & $32.75 \pm 0.27^{* * *}$ \\
\hline 9 & $56.64 \pm 1.53$ & $18.94 \pm 1.50^{*}$ & $46.62 \pm 1.69 * *$ \\
\hline 12 & $68.97 \pm 2.65$ & $57.41 \pm 1.76^{* *}$ & $51.25 \pm 0.84^{* * *}$ \\
\hline $\begin{array}{l}\text { Accumulation } \\
\left(\mu \mathrm{g} \mathrm{ml}^{-1} \mathrm{hr}^{-1}\right) \\
\text { Coefficient of }\end{array}$ & $4.42 \pm 0.16$ & $3.44 \pm 0.15^{\star *}$ & $2.91 \pm 0.16^{* * *}$ \\
\hline correlation $(r)$ & 0.994 & 0.986 & 0.991 \\
\hline
\end{tabular}

a Mean \pm SE.

$* p<0.05$.

** $p<0.01$.

$* * * 0<0.001$.

performed on the sample means. Significant differences $(p<0.05)$ were assigned by application of a computerized Scheffe-Bonferroni comparison of means (Neter and Wasserman, 1974).

\section{RESULTS}

\section{Lactate Levels}

Lactate concentrations were measured in the medium at $0,1,3,6,9$, and $12 \mathrm{hr}$ for each plate of Sertoli cells. No difference from controls was seen in lactate concentrations at either 3 or $10 \mathrm{mM} \mathrm{ME}$ at any time point. The rates of accumulation were also similar (Table 1). However, lactate concentration in the medium, as well as rate of lactate accumulation, were significantly decreased by both 3 and $10 \mathrm{mM} \mathrm{MA}$ at 6,9 , and $12 \mathrm{hr}$ of incubation (Table 2).

\section{Protein Synthesis}

No significant difference from controls was seen in protein synthesis, as determined by incorporation of radioactive leucine, after 12 
hr exposure to ME or MA at either 3 or 10 mM (Fig. 2). Plates averaged $138.8 \pm 19.9$ $\mu \mathrm{g}$ protein/plate. Cycloheximide inhibited protein synthesis by approximately $97 \%$ in each experiment.

\section{DISCUSSION}

This work was undertaken to elucidate a possible mechanism of action for testicular toxicity following exposure to ME. Because of the complexity of the physiological and biochemical processes of spermatogenesis and their apparent dependence on Sertoli cell products, the effects of ME and MA on cultured Sertoli cells were studied.

Viability of the cultures under the conditions of the experiment was verified by the linearity of lactate accumulation rate over the 12-hr incubation (see correlation coefficients, Tables 1 and 2), as well as the similarity in protein synthesis in the control and dosed plates.

Neither ME nor MA exposure for up to $12 \mathrm{hr}$ affected Sertoli cell protein synthesis in vitro. This finding is consistent with results reported by Chapin (1983), where total protein concentrations in fluid collected from the rete testes were unchanged in rats by $\mathrm{ME}$

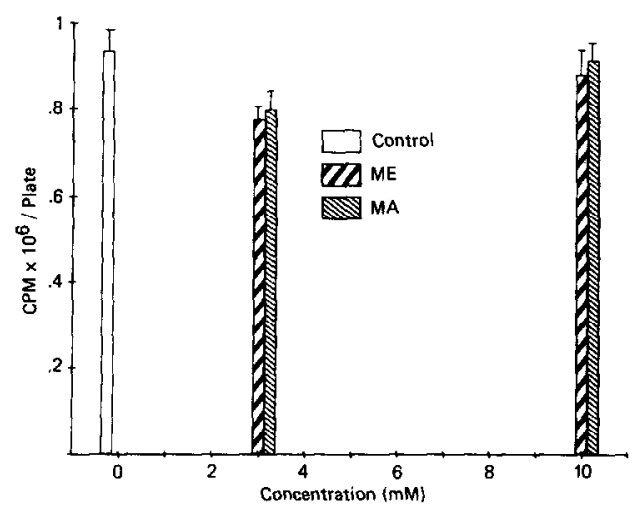

FIG. 2. Protein synthesis as determined by incorporation of radioactive leucine ( $25 \mu \mathrm{Ci} /$ plate). Sertoli cell cultures were incubated with ME or MA at 0,3 , and $10 \mathrm{mM}$ for $12 \mathrm{hr}$. No significant difference was seen from controls. treatment at $150 \mathrm{mg} / \mathrm{kg}, 5$ days/week (po) for up to 10 days.

MA decreased lactate production in Sertoli cells at the lowest concentration tested. A decrease in lactate would be unlikely to alter Sertoli cell function since these cells are often cultured without lactate with no noticeable adverse effects (Welsh and Wiebe, 1975; Jutte et al., 1981, 1982; Robinson and Fritz, 1981). However, we believe that this decrease could have detrimental effects on the viability of spermatocytes which appear to be the primary target following $\mathrm{ME}$ exposure in vivo. In germ cells isolated from rat testes, Jutte $e t$ al. (1981) reported that maximum stimulation of oxygen consumption and RNA and protein synthesis by pachytene spermatocyte or round spermatid preparations required an exogenous source of lactate. Degeneration of these cells was readily apparent after incubation without lactate within $24 \mathrm{hr}$. Jutte $e t$ al. (1982) found that isolated pachytene spermatocytes did not survive in the presence of glucose. However, if the cells were cultured with lactate or with Sertoli cells and glucose, the spermatocytes survived. These authors also conclude that for different stages of germ cell development, different carbohydrate substrates are required. For example, spermatocytes and round spermatids are dependent upon lactate, whereas spermatozoa may utilize glucose or fructose as substrates.

Since the spermatocyte is the first cell population to be depleted following ME or MA exposure, it is belicved that a decrease in availability of lactate as a result of decreased production by the Sertoli cells, as reported here, could lead to the disappearance of spermatocytes seen in vivo. The sensitivity of the testes to these compounds could also be explained in that a depletion of lactate, which would be critical for spermatogenesis, may not be critical in other organs. Indeed, our laboratory has observed a significant depletion in testicular, but not hepatic or plasma, lactate concentrations $24 \mathrm{hr}$ after a single po dose of $300 \mathrm{mg} / \mathrm{kg} \mathrm{ME}$ in adult rats (unpublished data). The depletion in 
lactate observed following incubation of Sertoli cells with MA, but not $\mathrm{ME}$, is also consistent with the hypothesis that MA is the toxic metabolite following ME exposure in vivo.

Our results suggest that a decrease in Sertoli cell lactate production caused by the metabolite, MA, may be a physiologically significant mechanism of toxicity in the testis following ME exposure. However, because other tissues, such as bone marrow and lymphoid tissues, are also affected, other mechanisms of action may contribute to the overall toxicity of ME.

\section{ACKNOWLEDGMENTS}

The authors thank Mr. Don Ayer for his laboratory assistance, and Ms. Patricia Houtteman for her assistance in preparation of the manuscript. This work was supported by NIH Grants HD15246 and HD17121 (MJW).

\section{REFERENCES}

BRABEC, M. J., BEDOWS, E., DAVIDSON, B., AND KNIGHT, P. R. (1984). Effect of general anesthetics and pressure on aerobic metabolism of monkey kidney cells. Anesthesiology 61, 43-48.

BRADFORD, M. (1976). A rapid and sensitive method for the quantitation of microgram quantities of protein utilizing principle of protein-dye binding. Anal. Biochem. 72, 248-254.

CHAPIN, R. E. (1983). Effects of various glycol ethers on testicular morphology, protein secretion and reproductive performance. In Toxic Effects of Glycol Ethers, NIOSH Symposium, Cincinnati, $\mathrm{OH}$.

DoE, J. E., Samuels, D. M., Tinston, D. J., AND DE Silva WiCKramaratNE, G. A. (1983). Comparative aspects of the reproductive toxicology by inhalation in rats of ethylene glycol monomethyl ether and propylene glycol monomethyl ether. Toxicol. Appl. Pharmacol. 69, 43-47.

Foster, P. M. D., Creasy, D. M., Foster, J. R., Thomas, L. V., CoOK, M. W., AND Gangolli, S. D. (1983). Testicular toxicity of ethylene glycol monomethyl and monoethyl ethers in the rat. Toxicol. Appl. Pharmacol. 69, 385-399.

HoHORST, H. J. (1965). L-(+)-Lactate: Determination with lactic dehydrogenase and DPN. In Methods of Enzymatic Analysis (H. U. Bergmeyer, ed.), pp. 266270. Verlag Chemie, Weinheim.

Jutte, N. H. P. M., Grootegoed, J. A., Rommerts, F. F. G., AND VAN DER MOLEN, H. J. (1981). Exogenous lactate is essential for metabolic activities in isolated rat spermatocytes and spermatids. $J$. Reprod. Fert. 62, 399-405.

Jutte, N. H. P. M., Jansen, R., Grootegoed, J. A., Rommerts, F. F. G., Clausen, O. P. F., and van DER MOLEN, H. J. (1982). Regulation of survival of rat pachytene spermatocytes by lactate supply from Sertoli cells. J. Reprod. Fert. 65, 431-438.

Kissinger, C., SKINNER, M. K., AND GRISWOLD, M. D. (1982). Analysis of Sertoli cell-secreted proteins by two-dimensional gel electrophoresis. Biol. Reprod. 27, 233-240.

MATHER, J. P. (1980). Establishment and characterization of two distinct mouse testicular epithelial cell lines. Biol. Reprod. 23, 243-252.

Miller, R. R., Ayres, J. A., Calhoun, L. L., Young, J. T., AND MCKenNA, M. J. (1981). Comparative short-term inhalation toxicity of ethylene glycol monomethyl ether and propylene glycol monomethyl ether in rats and mice. Toxicol. Appl. Pharmacol. 61, 368-377.

Miller, R. R., Carreon, R. E., Young, J. T., AND MCKENNA, M. J. (1982). Toxicity of methoxyacetic acid in rats. Fundam. Appl. Toxicol. 2, 158-160.

MILleR, R. R., AYRES, J. A., YOUNG, J. T., AND MCKENNA, M. J. (1983a). Ethylene glycol monomethyl ether. I. Subchronic vapor inhalation study with rats and rabbits. Fundam. Appl. Toxicol. 3, 49-54.

Miller, R. R., Hermann, E. A., LangVardt, P. W., MCKenNa, M. J., AND SchWETZ, B. A. (1983b). Comparative metabolism and disposition of ethylene glycol monomethyl ether and propylene glycol monomethyl ether in male rats. Toxicol. Appl. Pharmacol. 67, 229-237.

Neter, J., AND Wasserman, W. (1974). Applied Linear Statistical Models. Regression, Analysis of Variance, and Experimental Design, pp. 477-482. Richard D. Irwin, Homewood, Illinois.

ROBINSON, R., AND FrITZ, I. B. (1981). Metabolism of glucose by Sertoli cells in culture. Biol. Reprod. 24, 1032-1041.

SAMuels, D. M., DoE, J. E., AND Tinston, D. J. (1983). The effects on rat testis of single inhalation exposures to ethylene glycol alkyl ethers, in particular ethylene glycol monomethyl ether (EGME). In Presentation, European Society of Toxicology, Rome, Italy.

SKINNER, M. K., AND GRISWOLD, M. D. (1983). Sertoli cells synthesize and secrete a ceruloplasmin-like protein. Biol. Reprod. 28, 1225-1230.

Tash, J. S., Welsh, M. J., AND Means, A. R. (1981). Regulation of protein kinase inhibitor by folliclestimulating hormone in Sertoli cells in vitro. Endocrinology 108, 427-434.

Waites, G. M. H., and Gladwell, R. T. (1982). Physiological significance of fluid secretion in the testis and blood-testis barrier. Physiol. Rev. 62, 624-671.

WELSH, M. J., AND WIEBE, J. P. (1975). Rat Sertoli cells: A rapid method for obtaining viable cells. Endocrinology 96, 618-624. 